\title{
Legal Education against the Impact of Social Media in the Era of Information Disclosure for Pringgokusuman Residents in Yogyakarta
}

\author{
Dwi Oktafia Ariyanti ${ }^{1}$, Muhammad Ramadhan ${ }^{2}$ \\ 1,2 Faculty of Law, Universitas Janabadra, Indonesia \\ *Corresponding Author: M.Ramadhan, email: muhammad_ramadhan@janabadra.ac.id
}

\begin{abstract}
The purpose of this community service is to provide an understanding of the community on the impact of the use of social media in the current era of information disclosure. This is done so that people do not abuse the use of social media and are able to wisely utilize social media itself so as not to cause negative effects. Partners of community service activities are residents of Pringgokusuman, Gedongtengen, Yogyakarta. Education provided includes an understanding of the negative and positive impacts of using social media, the role of families, especially parents, in supervising the use of social media and the legal rules used to overcome problems arising from the use of social media. Many impacts arising from the use of social media. The negative impacts of using social media must be immediately prevented and acted upon because the negative impacts are spread very quickly and are detrimental to users and the community. In addition there are also positive impacts arising from the use of social media that can provide developments both in terms of social and material for the community.
\end{abstract}

Keywords: legal education; social media impacts; information disclosure era

\section{How to cite:}

Ariyanti, D.O., \& Ramadhan, M. (2019). 'Legal Education against the Impact of Social Media in the Era of Information Disclosure for Pringgokusuman Residents in Yogyakarta.' Indonesian Journal of Advocacy and Legal Services, 1(1), 129-134. DOI: 10.15294/ijals.v1i1.33768 


\section{A. Introduction}

The internet can be said to be the end of the greatest invention of information technology devices and technologies that have the greatest impact on humans. In this era it can be said that society cannot be separated from dependence on technology. However, the point of view of advances in information and communication technology is not only based on the presence of increasingly sophisticated communication devices, but also has an influence on culture that occurs in the community.

The development of science and technology ushered people into the digital era which gave birth to the internet as a network including in one's contact with other parties, even internet technology is able to convert data, information, audio, visuals that can affect human life (Widodo, 2013).

One impact caused by the rapid development of information technology is the increasingly widespread crime through social media. This is inseparable from the many users of social media from children to adults, through social media they can channel all opinions and forms of protest that can sometimes lead to acts against the law.

Teenagers as the most active users and almost every day interacting using social media, directly messages or information on social media are very quickly spread among adolescents, information that is spread through social media routinely and listened by teenagers directly leads to the formation of opinion among the adolescents are very vulnerable to lead to things that negatively affect adolescents themselves.

In Indonesia there are legislation that specifically regulates information and electronic transactions, especially in the use of social media, namely Law Number 11 of 2008 concerning Information and Electronic Transactions which has now been changed to Law Number 19 of 2016 concerning Changes to Law Number 11 of 2008 Rconcerning Information and Electronic Transactions.

Society often lacks understanding of its subordinates in the misuse of social media can lead to actions against the law. So from this it is necessary to have legal education regarding the use of social media so that people can be smarter in using social media.

\section{B. Method}

Partners of community service activities are residents of Pringgokusuman, Kec. Gedongtengen, Yogyakarta, which consists of teenagers and parents. This activity includes providing education to Pringgokusuman residents in 
using social media in order to produce positive impacts and avoid negative impacts. The education provided includes an understanding of the negative and positive impacts of using social media, the role of families, especially parents, in supervising the use of social media and the rule of law used to overcome problems arising from the use of social media.

\section{Result and Discussion}

1. Crimes and Technological Development: Negative and Positive Impacts

Technological progress is very potential for the emergence of various forms of criminal acts the internet can be a medium that makes it easy for someone to commit various criminal actions based on information technology (cybercrime). The internet beside recognized as a tool for disseminating information and a media for collaborating, also use for interacting between individuals using computers without boundaries.

The growth of the internet that is spreading rapidly within the community is very vulnerable to the abuse of the internet itself. Easy access to the internet from various groups of children, adolescents to parents, if not followed by a correct understanding of its use can cause various negative impacts.

Negative impacts arising from the misuse of the internet especially social media itself include:

1) Addiction

Excessive use of social media can cause dependency. One can use social media for more than 8 hours a day. Even now a person can not be separated from the use of the internet, especially social media, even this has also become a new disease such as Facebook depression. This initial disease looks the same as anxiety, psychological disorders, dependency or other bad habits. Even now the disease is not only on Facebook but almost all social media. Social networks can be considered as the creators of depression for its users.

2) Cannot Control Yourself

Addictive users of social media are considered unable to control themselves. For those who experience acute addiction, even having low self-control, they tend not to be able to control themselves to use social media. According to researchers, users are too concerned about their image on social media, especially self-esteem to their closest friends. They feel through social media they can express everything they are feeling and share what they are doing. In such a case the thing that was originally a private matter became public consumption. And other people 
tend to be able to comment anything from something that should be personal.

3) Danger of Crime

Technological progress is very potential for the emergence of various forms of criminal acts, the internet can be a medium that makes it easy for someone to commit various criminal actions based on information technology (cybercrime). The internet as a tool for disseminating information and a media for collaborating and interacting between individuals using computers without boundaries. By paying attention to the characteristics of the internet so specifically the internet can be a medium that makes it easy for someone to commit various types of criminal acts based on information technology (cybercrime) such as criminal acts of defamation, gambling, fraud, pornography to criminal acts of terrorism (cyber terrorism).

Furthermore, beside the negative impacts, social media as well as technological development also has some positive impacts, as follows:

1) As a Promotion Place

By using social media, this allows small entrepreneurs to promote their products and services without spending much money. Even by using social media, entrepreneurs do not need to provide a special place to market their production. Everyone can immediately see the products to be marketed and entrepreneurs can establish a close buying and selling relationship with customers.

2) Increase Friends and Relations

Social media has a positive impact on its users, by using social media we can expand the network of friends and can communicate with anyone, even with people we do not know even from various parts of the world.

3) As a Communication Media

Social media as a communication media is the most widely used social media function where every social media user can communicate with other users from anywhere. With the convenience offered by social media, many people use it as a means of communication.

4) Information Sharing

The rapid development of the internet has made social media a source of information for the community, with the ease of obtaining information through social media making it no longer difficult for people to obtain important information. 


\section{Legal Provisions on Social Media}

One impact caused by the rapid development of information technology is the increasingly widespread crime through social media. This is inseparable from the many users of social media from children to adults, through social media they can channel all opinions and forms of protest that can sometimes lead to acts against the law.

In Indonesia, prior to the provision of specific regulations regarding information and electronic transactions, the perpetrators of media misuse were subject to the rules contained in the main law, the Criminal Code (KUHP). It is still not effective enough to overcome the problems arising from social media in particular. Therefore, a special law was formed, namely Law No. 11/2008 concerning Information and Electronic Transactions which has now been amended to Law No. 19/16 concerning Amendment to Law No. 11/2008 concerning Information and Electronic Transactions. The criminal acts of information and electronic transactions are regulated in 9 Articles from Article 27 to Article 35, in these Articles describe criminal acts in the field of information and electronic transactions

With the promulgation of Law Number 11 of 2008 which has now been amended by Law Number 19 Year 2016 concerning Amendment to Law Number 11 of 2008 concerning Information and electronic transactions, the purpose of the promulgation of the Act is to be carried out optimally, evenly and spread throughout the community about knowledge about information and electronic transactions in order to educate the nation's life. Changes in the life of society in various fields will directly affect the birth of forms of new legal actions.

\section{Conclusion}

The impact of social media is a condition where a person is dependent on the latest technology. In the community environment, almost all people have used social media. The development of social media technology has mushroomed and rooted in everyday life and has changed lifestyles and even thought patterns. The negative and positive impacts arising from social media itself. The negative impacts must be immediately prevented and acted upon because the negative impacts are spread very quickly. Then the role of parents and the environment is needed to anticipate the abuse of social media. Not only the negative impacts, but also the positive impacts arising from the use of social media. These positive impacts can provide developments both in social and material terms for the community. and it needs to be understood that in Indonesia there are legislation that 
specifically regulates Law Number 11 of 2008 which has now been amended by Law Number 19 of 2016 concerning Amendments to Law Number 11 of 2008 concerning Information and Transactions electronic.

\section{E. Acknowledgments}

Thank to all faculty members of Faculty of Law, Universitas Janabarda, Yogyakarta, Indonesia.

\section{F. Declaration of Conflicting Interests}

The authors state that there is no potential conflict of interest in the research, authorship, and / or publication / publication of this article.

\section{G. Funding}

Program of the community services and research funded by Faculty of Law, Universitas Janabadra, Yogyakarta, Indonesia.

\section{H. References}

Marpaung, L. (2009). Asas-Teori-Praktik Hukum Pidana. Jakarta: Sinar Grafika Prodjodikoro, W. (2002). Tinda-Tindak Pidana Tertentu di Indonesia. Bandung: PT. Refika

Widodo. (2009). Sistem Pemidanaan Dalam Cybercrime. Yogyakarta: Laksbang Mediatama

Widodo. (2013). Hukum Pidana di Bidang Teknologi Informasi. Yogyakarta: Aswaja Pressindo

Undang-Undang Dasar Negara Republik Indonesia Tahun 1945

Undang-Undang Nomor 1 Tahun 1946 tentang Kitab Undang-Undang Hukum Pidana, Lembaran Negara Republik Indonesia Tahun 1958 Nomor 127, Tambahan Lembaran Negara

Undang-undang Nomor 19 Tahun 2016 Tentang Perubahan Atas Undang-undang Nomor 11 Tahun 2008 Tentang Informasi dan Transaksi Elektronik

[...] http://elib.unikom.ac.id/ Ruang Lingkup dan Penyelenggaraan Pers di Indonesia

Copyrights (C) 2019 by Auhtor(s). This work is licensed under a Creative Commons Attribution-NonCommercial-ShareAlike 4.0 International License. All writings published in this journal are personal views of the authors and do not represent the views of this journal and the author's affiliated institutions. 